\title{
PENDEKATAN MODEL VECTOR AUTOREGRESSIVE (VAR) UNTUK MERAMALKAN FAKTOR-FAKTOR YANG MEMPENGARUHI INFLASI DI PROVINSI GORONTALO
}

\author{
Hariyati H. Usman ${ }^{1}$, Ismail Djakaria ${ }^{2}$, Muhammad Rezky Friesta Payu ${ }^{3}$ \\ ${ }^{1,2,3}$ Program Studi Statistika, Fakultas Matematika dan IPA, Universitas Negeri Gorontalo \\ e-mail: hariyatiusman44@gmail.com
}

\begin{abstract}
Abstrak
Model Vector autoregresive (VAR) merupakan pemodelan persamaan simultan yang digunakan untuk menyusun sistem peramalan dari data time series yang saling terkait. Penelitian ini bertujuan untuk meramalkan faktor-faktor yang secara signifikan berpengaruh terhadap inflasi di provinsi Gorontalo. Data yang digunakan dalam penelitian ini adalah data Inflasi dan faktor-faktor yang mempengaruhi Inflasi setiap bulan di provinsi Gorontalo periode Januari 2009 - Desember 2018. 3. Berdasarkan model VAR (1), hasil peramalan inflasi di provinsi Gorontalo untuk tahun 2019 menunjukkan bahwa pada awal tahun 2019 inflasi di provinsi Gorontalo terbilang sangat rendah yakni sekitaran $-0,48 \%$ sampai $-0,40 \%$. Akan tetapi inflasi akan melonjak naik pada bulan Maret 2019 dengan tingkat inflasi sebesar -0,25\% (tingkat inflasi tertinggi ada pada bulan Maret 2019). Pada bulan April dan Mei inflasi mengalami penurunan menjadi $-0.30 \%$ dan $-0,33 \%$. Setelah mengalami penurunan tingkat inflasi pada bulan April dan Mei, pada pertengahan tahun (bulan Juni) inflasi di provinsi Gorontalo mengalami peningkatan kembali menjadi $-0,31 \%$ dan tidak akan mengalami banyak perubahan sampai akhir tahun yakni tetap berkisar di angka $-0,32 \%$. Keakuratan hasil prediksi dilihat pada nilai MAPE dari data out sampel variabel $Y_{1}$ sampai $Y_{8}$ rata-rata dibawah $10 \%$ artinya model VAR mempunyai kemampuan peramalan yang sangat baik.
\end{abstract}

Kata Kunci: Inflasi, Time Series Multivariate, VAR

\begin{abstract}
The vector autoregressive (VAR) model is a simultaneous equation modeling used to construct forecasting systems from interrelated time-series data. This study intends to predict factors that significantly influence inflation in the province of Gorontalo. Moreover, the data used in this study involved inflation data and factors that influence inflation every month in the province in the period of January 2009 - December 2018. The results of inflation forecasting in Gorontalo in 2019 show that at the beginning of 2019, the inflation was considered to be very low at around $-0.48 \%$ to $0.40 \%$. However, the inflation surged in March with $-0.25 \%$ (the highest inflation rate). The percentage decreased to - $0.30 \%$ and $-0.33 \%$ in April and May. After the decline in April and May, in the middle of the year (June) inflation returned to $-0.31 \%$ and did not experience a significant change until the end of the year, which was still in the range of -0.32\%. The accuracy of the prediction results seen in the MAPE value from out sample data of variables $Y_{1}$ to $Y_{8}$ is on the average below 10\%, indicating that VAR is a significant forecasting model.
\end{abstract}

Keywords: Inflation, Time Series Multivariate, VAR. 


\section{PENDAHULUAN}

Analisis time series merupakan serangkaian pengamatan terhadap suatu variabel yang diamati dari waktu ke waktu (Ekananda, 2016). Secara umum analisis data time series yang digunakan adalah model ARIMA. Tetapi model ARIMA digunakan apabila data time series hanya berupa satu variabel. Jika data time series terdiri dari beberapa variabel, maka digunakan time series multivariat yaitu model Vector Autoregresive (VAR) (Prahutama et al. 2019)

Pendekatan model Vector Autoregressive (VAR) diterapkan jika struktur model yang ada membuat setiap variabel fungsi sebagai variabel endogen yang merupakan fungsi dari nilai-nilai lag seluruh variabel endogen yang ada pada sistem. Jadi, variabel penjelas dalam Vector Autoregressive (VAR) meliputi nilai lag seluruh variabel tak bebas. Prosedur pemodelan Vector Autoregressive (VAR) harus memenuhi beberapa asumsi agar model baik digunakan dan dipakai dalam meramalkan. Asumsi tersebut seperti data yang stasioner dalam mean dan varians, semua sisaan bersifat white noise yaitu memiliki rataan nol, ragam dan konstan serta diantara variabel tak bebas tidak korelasi (Suhel 2008).

Beberapa penelitian terkait dengan model Vector Autoregressive (VAR) adalah (Desvina and Juliana 2016) menggunakan model Vector Autoregresive (VAR) untuk memodelkan pencemaran udara di provinsi Riau. Hasil yang diperoleh menunjukkan bahwa model yang sesuai untuk peramalan pencemaran udara adalah dengan menggunakan model Vector Autoregressive (VAR) 1. Model Vector Autoregressive (VAR) 1 yang diperoleh dapat disimpulkan bahwa unsur curah hujan, radiasi, matahari, suhu udara, dan hotspot memiliki hubungan yang searah terhadap pencemaran udara. Selanjutnya (Hardani et al. 2016) menggunakan model Vector Autoregressive (VAR) untuk meramalkan laju inflasi, suku bunga indonesia dan indeks harga saham gabungan. Model Vector Autoregressive (VAR) terbaik yang dihasilkan menggunakan model VAR (4). Berdasarkan hasil peramalan, nilai inflasi mengalami fluktuasi yang stabil sedangkan suku bunga indonesia dan indeks harga saham gabungan mengalami kenaikan dan penurunan pada periode 4 dan 5 .

Salah satu implementasi model Vector Autoregressive (VAR) adalah pemodelan pada faktor-faktor inflasi. Inflasi merupakan dilema yang menghantui perekonomian setiap negara, apalagi bagi negara-negara berkembang yang ada di dunia khususnya di Indonesia. Secara sederhana Inflasi diartikan sebagai kenaikan harga barang dan jasa secara umum dimana barang dan jasa tersebut merupakan kebutuhan pokok masyarakat atau turunnya daya jual mata uang suatu negara. Inflasi menjadi salah satu indikator ekonomi yang selalu diperhatikan oleh pemerintah, saat ini Indonesia (Bank Indonesia) menggunakan kebijakan target inflasi (Hendajany 2015). Berdasarkan uraian tersebut, dilakukan penelitian dengan judul "Pendekatan Model Vector Autoregressive (VAR) untuk Meramalkan Faktor-Faktor yang Mempengaruhi Inflasi di Provinsi Gorontalo".

\section{METODE PENELITIAN}

Data yang digunakan pada penelitian ini adalah data sekunder yaitu data yang diambil dari website resmi Badan Pusat Statistik (BPS) dari tahun 2009-2018 (BPS 2018). Data tersebut 
didapat dari Badan Pusat Statistik provinsi Gorontalo melalui official website gorontalo.bps.go.id. Adapun langkah-langkah analisis data yang dilakukan dalam penelitian ini adalah:

1. Melakukan pemeriksaan kestasioneran data menggunakan $A D F$ Jika data tidak stasioner dalam variansi maka dilakukan transformasi logaritma natural (penstabilan variansi). Jika sudah staioner dalam varians dilanjutkan dengan uji stasioner dalam mean jika belum stasioner dalam mean maka dilakukan proses pembeda (diffrencing).

2. Melakukan pengujian lag optimal yang bertujuan untuk menentukan panjang lag optimal dengan menggunakan kuadrat terkecil nilai $A I C$.

3. Melakukan pengujian kausalitas granger guna melihat hubungan antar hubungan.

4. Melakukan estimasi parameter model VAR menggunakan $\underline{O L S}$.

5. Melakukan diagnostik model dilihat dari uji Portmanteau dan uji nomality test.

6. Model terbaik berdasarkan nilai AIC.

7. Menentukan nilai peramalan model VAR.

8. Menentukan ketepatan peramalan berdasarkan nilai $M A P E$

Untuk memudahkan dalam hal komputasi, khususnya dalam menentukan model dan meramalkan, akan digunakan software SAS.

\section{HASIL DAN PEMBAHASAN}

\subsection{Pemodelan Vector Autoregressive (VAR)}

Pada tahapan ini dilakukan pemodelan VAR dengan beberapa tahapan. Tahap yang pertama identifikasi model dan pengecekan kestasioneran data, tahap kedua penentuan lag optimum, tahap ketiga estimasi parameter, tahap keempat pengujian granger causality, tahap terakhir yaitu pengujian asumsi residual.
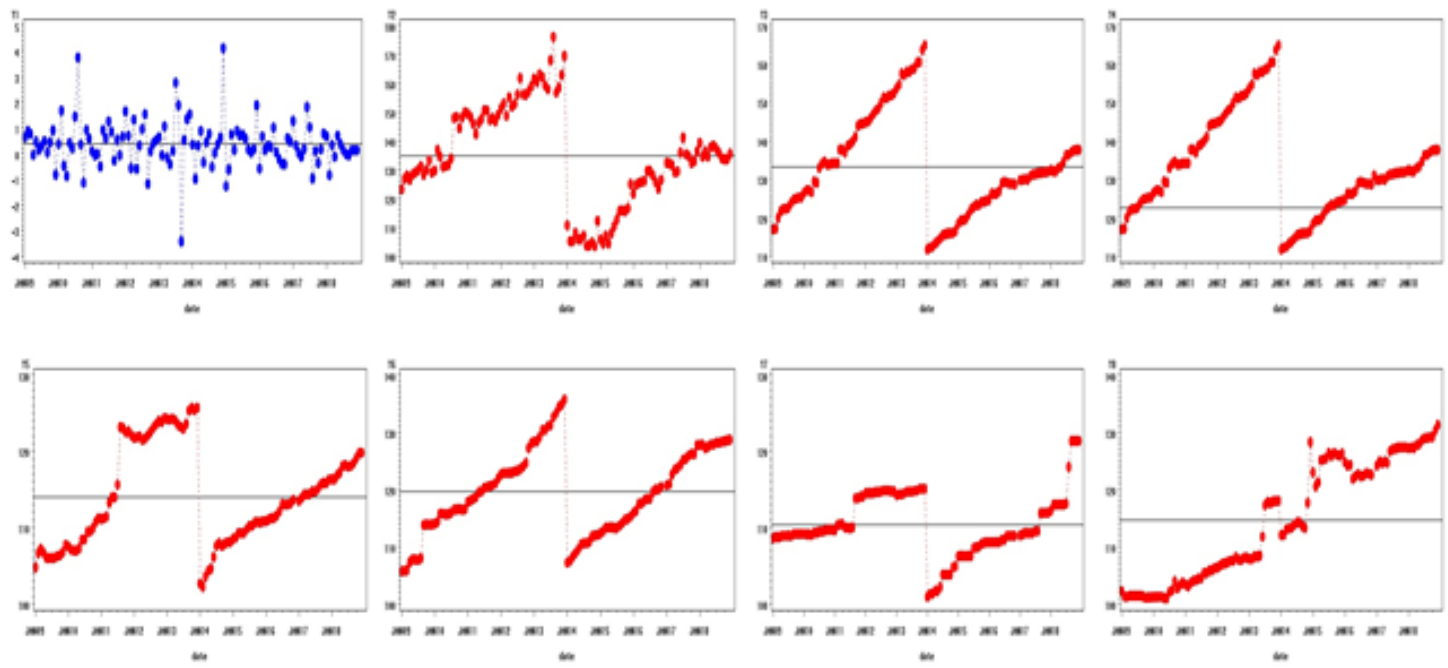

Gambar 1. Plot Inflasi

Plot time series pada gambar $1 \mathrm{Y}_{1}$ menunjukkan bahwa data $\mathrm{Y}_{1}$ sudah stasioner dalam ratarata, hal ini terlihat dari plot time series yang menunjukkan data berfluktuasi di sekitar nilai rata-ratanya. Sedangkan untuk data sektor makanan $\mathrm{Y}_{2}$ sampai sektor transportasi komunikasi dan jasa keuangan $\mathrm{Y}_{8}$ menunjukkan bahwa datanya tidak stasioner dalam ratarata, hal ini terlihat pada Gambar $\mathrm{Y}_{2}$ sampai $\mathrm{Y}_{8}$ yang menunjukkan pola trend pada beberapa tahun tertentu. Hal ini mengindikasikan bahwa perlu dilakukan differencing untuk membuat data sektor makanan $Y_{1}$ sampai sektor transportasi komunikasi dan jasa keuangan $Y_{8}$ menjadi 
stasioner dalam rata-rata. Oleh karena itu, pada data $\mathrm{Y}_{2}$ sampai $\mathrm{Y}_{8}$ perlu dilakukan transformasi dan differencing untuk membuat data menjadi stasioner dalam varians dan ratarata. Transformasi dilakukan dengan menggunakan fungsi logaritma natural. Menurut (Ohyver 2013), metode transformasi logaritma natural dapat membuat model bebas multikolinieritas dan asumsi normalitas dapat terpenuhi. Berikut adalah hasil uji stasioner menggunakan uji $A D F$ yang disajikan dalam Tabel 1.

Tabel 1: Nilai statistic Uji $A D F$, data setelah di transformasi dan differencing

\begin{tabular}{|c|c|}
\hline Lag & AIC \\
\hline 0 & $-7369,72$ \\
\hline 1 & $-7569,14$ \\
\hline 2 & $-7468,75$ \\
\hline 3 & $-7409,12$ \\
\hline 4 & $-7361,63$ \\
\hline 5 & $-7360,85$ \\
\hline 6 & $-7325,36$ \\
\hline 7 & $-7286,84$ \\
\hline 8 & $-7264,25$ \\
\hline 9 & $-7235,32$ \\
\hline 10 & $-7242,22$ \\
\hline
\end{tabular}

Tabel 1 menunjukkan bahwa hasil pengujian untuk variabel $\mathrm{Y}_{1}$ sampai $\mathrm{Y}_{8}$ memperoleh $\quad p$ value $<0.0001$. Sehingga $p$-value $<\alpha=0.05$ dan tolak $\mathrm{H}_{0}$. Sehingga dapat dikatakan bahwa pada level kepercayaan $5 \%$ variabel $\mathrm{Y}_{1}$ sampai $\mathrm{Y}_{8}$ sudah stasioner.

\subsection{Penentuan Lag Optimum}

Setelah data sudah stasioner, maka langkah selanjutnya adalah penentuan lag optimum untuk model VAR. Besarnya lag yang dipilih adalah lag yang menghasilkan nilai AIC paling kecil ditampilkan pada Tabel 2.

Tabel 2 Nilai $A I C$ model $V A R$

\begin{tabular}{|c|c|c|c|}
\hline Data & Thitung & $\boldsymbol{p}$-value & Keterangan \\
\hline$Y_{1}$ & $-14,60$ & $<0,0001$ & Stasioner \\
\hline$Y_{2}$ & $-8,81$ & $<0,0001$ & Stasioner \\
\hline$Y_{3}$ & $-7,96$ & $<0,0001$ & Stasioner \\
\hline$Y_{4}$ & $-7,70$ & $<0,0001$ & Stasioner \\
\hline$Y_{5}$ & $-7,87$ & $<0,0001$ & Stasioner \\
\hline$Y_{1}$ & $-7,77$ & $<0,0001$ & Stasioner \\
\hline$Y_{7}$ & $-7,38$ & $<0,0001$ & Stasioner \\
\hline$Y_{8}$ & $-9,47$ & $<0,0001$ & Stasioner \\
\hline
\end{tabular}

Berdasarkan Tabel 2 diketahui bahwa nilai AIC yang terkecil adalah pada lag 1 dengan nilai AIC sebesar $-7569,14$. Hal ini berarti lag 1 digunakan untuk penentuan model karena pada lag ini $A I C$-nya paling kecil diantara lag-lag yang lain. Oleh karena itu, uji diagnostik dilakukan lebih dulu pada $\operatorname{VAR}(1)$ dengan differencing 1 kali.

\subsection{Estimasi Parameter Untuk Model VAR(1)}

Pada tahap ini akan dicari estimasi model $V A R(1)$ Adapun metode yang digunakan pada penelitian ini adalah metode $O L S$ atau metode kuadrat terkecil dengan mendapatkan model 
dengan residual minimum dilakukan dengan cara mengkuadratkan residual maka diperoleh estimasi parameter $\beta$ (Supranto 2005). Hasil yang diperoleh untuk estimasi parameternya melalui $O L S$ ditampilkan pada Tabel 3.

Tabel 3 Hasil Estimasi Parameter Model VAR(1)

\begin{tabular}{|c|c|c|c|c|c|}
\hline Sektor & Parameter & Estimasi & S, Error & $\mathrm{P}_{\text {_value }}$ & Variabel \\
\hline \multirow[t]{8}{*}{$\mathrm{Y}_{1}$} & $\phi_{11}^{1}$ & 0,330 & 0,098 & 0,0011 & $\mathrm{Y}_{1(\mathrm{t}-1)}$ \\
\hline & $\phi_{12}^{1}$ & $-43,688$ & 4,584 & 0,0001 & $\mathrm{Y}_{2(\mathrm{t}-1)}$ \\
\hline & $\phi_{13}^{1}$ & 36,339 & 10,653 & 0,0009 & $\mathrm{Y}_{3(\mathrm{t}-1)}$ \\
\hline & $\phi_{14}^{1}$ & 15,663 & 12,239 & 0,2033 & $\mathrm{Y}_{4(\mathrm{t}-1)}$ \\
\hline & $\phi_{15}^{1}$ & 2,574 & 11,386 & 0,8215 & $\mathrm{Y}_{5(\mathrm{t}-1)}$ \\
\hline & $\phi_{16}^{1}$ & 3,612 & 12,019 & 0,7643 & $\mathrm{Y}_{6(\mathrm{t}-1)}$ \\
\hline & $\phi_{17}^{1}$ & $-5,266$ & 13,567 & 0,6986 & $Y_{7(t-1)}$ \\
\hline & $\phi_{18}^{1}$ & $-9,624$ & 6,423 & 0,1369 & $\mathrm{Y}_{8(\mathrm{t}-1)}$ \\
\hline \multirow[t]{8}{*}{$\mathrm{Y}_{2}$} & $\phi_{21}^{1}$ & 0,015 & 0,005 & 0,0029 & $Y_{1(t-1)}$ \\
\hline & $\phi_{22}^{1}$ & $-0,889$ & 0,230 & 0,0002 & $\mathrm{Y}_{2(\mathrm{t}-1)}$ \\
\hline & $\phi_{23}^{1}$ & 0,867 & 0,534 & 0,1079 & $Y_{3(t-1)}$ \\
\hline & $\phi_{24}^{1}$ & 0,555 & 0,614 & 0,3680 & $\mathrm{Y}_{4(\mathrm{t}-1)}$ \\
\hline & $\phi_{25}^{1}$ & $-0,019$ & 0,571 & 0,9834 & $Y_{5(t-1)}$ \\
\hline & $\phi_{26}^{1}$ & $-0,271$ & 0,603 & 0,6542 & $\mathrm{Y}_{6(\mathrm{t}-1)}$ \\
\hline & $\phi_{27}^{1}$ & $-0,346$ & 0,681 & 0,6127 & $Y_{7(\mathrm{t}-1)}$ \\
\hline & $\phi_{28}^{1}$ & 0,199 & 0,322 & 0,5372 & $\mathrm{Y}_{8(\mathrm{t}-1)}$ \\
\hline
\end{tabular}

Berdasarkan Tabel 3 diketahui bahwa dari 64 parameter hasil estimasi, hanya 5 parameter yang signifikan pada taraf signifikansi 5\% terdapat pada sektor inflasi $\mathrm{Y}_{1}$ ada 3 parameter yang singinfikan yaitu inflasi, sektor makanan, dan sektor makanan jadi, minuman, rokok dan tembakau dan pada sektor makanan $\mathrm{Y}_{1}$ parameter yang signifikansi ada 2 yaitu inflasi dan sektor makanan. Hal ini dapat dilihat dari nilai $p-$ value $<\alpha=5 \%$.

\subsection{Pengujian Granger Causality $\operatorname{VAR}(1)$}

Pengujian Granger Causality digunakan untuk mengetahui hubungan antar variabel apakah terdapat hubungan searah atau kausal (dua arah).Berikut ini merupakan hasil pengujian Granger Causality antara variabel. Uji hubungan kausal granger yang dilakukan terhadap ke-8 variabel ditampilkan pada Tabel 4. 
Tabel 4 Pengujian kausalitas Granger VAR (3)

\begin{tabular}{|c|c|c|c|c|c|}
\hline Kausal & $\mathbf{H}_{\mathbf{0}}$ & $\begin{array}{l}\text { Chi- } \\
\text { Square }\end{array}$ & df & p-value & Kesimpulan \\
\hline 1 & $\begin{array}{l}\mathrm{y}_{2}, \mathrm{y}_{3}, \mathrm{y}_{4}, \mathrm{y}_{5}, \mathrm{y}_{6}, \mathrm{y}_{7}, \mathrm{y}_{8} \text { tidak } \\
\text { mempengaruhi } \mathrm{y}_{1}\end{array}$ & 99,17 & 7 & $<0,0001$ & Tolak $\mathrm{H}_{0}$ \\
\hline 2 & $\begin{array}{l}\mathrm{y}_{1}, \mathrm{y}_{3}, \mathrm{y}_{4}, \mathrm{y}_{5}, \mathrm{y}_{6}, \mathrm{y}_{7} \text {, tidak } \\
\text { mempengaruhi } \mathrm{y}_{2}\end{array}$ & 17,05 & 7 & 0,0171 & Tolak $\mathrm{H}_{0}$ \\
\hline 3 & $\begin{array}{l}\mathrm{y}_{1}, \mathrm{y}_{2}, \mathrm{y}_{4}, \mathrm{y}_{5}, \mathrm{y}_{6}, \mathrm{y}_{7}, \mathrm{y}_{8} \text { tidak } \\
\text { mempengaruhi } \mathrm{y}_{3}\end{array}$ & 3,83 & 7 & 0,7993 & Gagal tolak $\mathrm{H}_{0}$ \\
\hline 4 & $\begin{array}{l}\mathrm{y}_{1}, \mathrm{y}_{2}, \mathrm{y}_{3}, \mathrm{y}_{5}, \mathrm{y}_{6}, \mathrm{y}_{7}, \mathrm{y}_{8} \text { tidak } \\
\text { mempengaruhi } \mathrm{y}_{4}\end{array}$ & 5,09 & 7 & 0,6486 & Gagal tolak $\mathrm{H}_{0}$ \\
\hline 5 & $\begin{array}{l}\mathrm{y}_{1}, \mathrm{y}_{2}, \mathrm{y}_{3}, \mathrm{y}_{4}, \mathrm{y}_{6}, \mathrm{y}_{7} \text {, tidak } \\
\text { mempengaruhi } \mathrm{y}_{5}\end{array}$ & 3,35 & 7 & 0,8505 & Gagal tolak $\mathrm{H}_{0}$ \\
\hline 6 & $\begin{array}{l}\mathrm{y}_{1}, \mathrm{y}_{2}, \mathrm{y}_{3}, \mathrm{y}_{4}, \mathrm{y}_{5}, \mathrm{y}_{7}, \mathrm{y}_{8} \text { tidak } \\
\text { mempengaruhi } \mathrm{y}_{16}\end{array}$ & 2,80 & 7 & 0,9031 & Gagal tolak $\mathrm{H}_{0}$ \\
\hline 7 & $\begin{array}{l}\mathrm{y}_{1}, \mathrm{y}_{2}, \mathrm{y}_{3}, \mathrm{y}_{4}, \mathrm{y}_{5}, \mathrm{y}_{6}, \mathrm{y}_{8} \text { tidak } \\
\text { mempengaruhi } \mathrm{y}_{7}\end{array}$ & 9,93 & 7 & 0,1928 & Gagal tolak $\mathrm{H}_{0}$ \\
\hline 8 & $\begin{array}{l}\mathrm{y}_{1}, \mathrm{y}_{2}, \mathrm{y}_{3}, \mathrm{y}_{4}, \mathrm{y}_{5}, \mathrm{y}_{6}, \mathrm{y}_{7} \text { tidak } \\
\text { mempengaruhi } \mathrm{y}_{8}\end{array}$ & 7,63 & 7 & 0,3663 & Gagal tolak $\mathrm{H}_{0}$ \\
\hline
\end{tabular}

Berdasarkan Tabel 4 diketahui bahwa dari 64 parameter hasil estimasi, hanya 5 parameter yang signifikan pada taraf signifikansi 5\% terdapat pada sektor inflasi $\mathrm{Y}_{1}$ ada 3 parameter yang singinfikan yaitu inflasi, sektor makanan, dan sektor makanan jadi, minuman, rokok dan tembakau dan pada sektor makanan $Y_{2}$ parameter yang signifikansi ada 2 yaitu inflasi dan sektor makanan. Hal ini dapat dilihat dari nilai $p-$ value $<\alpha=5 \%$.

\subsection{Pengujian Asumsi Residual VAR(1)}

\subsubsection{Uji white noise}

Tujuan dari uji asumsi residual white noise adalah untuk mengetahui apakah data korelasi antar vektor residual dari VAR (1) yang telah terbentuk. Pengujian multivariate white noise melalui uji portmanteau ditampilkan pada Tabel 5.

Tabel 5 Pengujian white noise VAR (1)

\begin{tabular}{|c|c|c|}
\hline Lag & p-value & Keputusan \\
\hline 2 & 0,205 & Gagal Tolak $\mathrm{H}_{0}$ \\
\hline 3 & 0,800 & Gagal Tolak $\mathrm{H}_{0}$ \\
\hline 4 & 0,819 & Gagal Tolak $\mathrm{H}_{0}$ \\
\hline 5 & 0,387 & Gagal Tolak $\mathrm{H}_{0}$ \\
\hline 6 & 0,422 & Gagal Tolak $\mathrm{H}_{0}$ \\
\hline 7 & 0,728 & Gagal Tolak $\mathrm{H}_{0}$ \\
\hline 8 & 0,934 & Gagal Tolak $\mathrm{H}_{0}$ \\
\hline 9 & 0,968 & Gagal Tolak $\mathrm{H}_{0}$ \\
\hline 10 & 0,958 & Gagal Tolak $\mathrm{H}_{0}$ \\
\hline 11 & 0,881 & Gagal Tolak $\mathrm{H}_{0}$ \\
\hline 12 & 0,809 & Gagal Tolak $\mathrm{H}_{0}$ \\
\hline
\end{tabular}


Tabel 5 menunjukkan bahwa pada taraf signifikansi 5\% untuk lag 2 sampai lag 12 mempunyai $p$-value $>\alpha=5 \%$. Hal ini memberikan gambaran bahwa model VAR (1) sudah memenuhi asumsi Multivariate white noise.

\subsubsection{Uji Asumsi Residual Normal Multivariate}

Secara visual normal multivariate dapat dilihat dari gambar Q-Q plot distibusi normal multivariate residual VAR (1) ditampilkan pada Gambar 2.

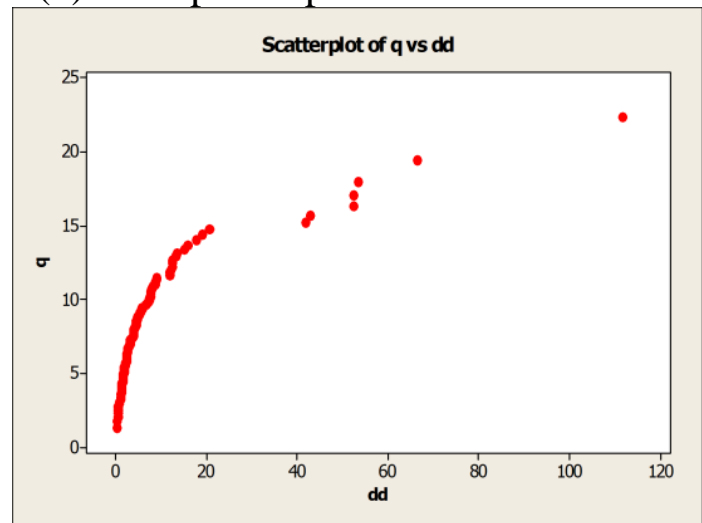

Gambar 2 Plot residual distribusi normal multivariate VAR (1)

Gambar 2 terlihat bahwa plot residual tidak mengikuti garis linier, hal ini mengindikasikan bahwa residual tidak berdistribusi normal multivariate artinya bahwa nilai $d \frac{2}{j} \leq \chi^{2}$ lebih dari 50\% yaitu 74\%. Hal berarti bahwa residual berdistribusi normal multivariate.

Berdasarkan uraian di atas diketahui bahwa model VAR (1) sudah memenuhi uji kesesuaian model maka model terbaik adalah VAR (1), karena VAR (1) memenuhi asumsi white-noise dan multivariate normal dan memiliki 5 parameter yang signifikan serta merupakan model yang nilai $A I C$ paling kecil. Model VAR (1) pada persamaan 1 dapat dijabarkan untuk masing-masing sektor yakni sektor inflasi, sektor makanan, sektor makanan jadi, minuman, rokok dan tembakau, sektor perumahan, listrik, air, gas dan bahan bakar, sektor sandang, sektor kesehatan, sektor pendidikan dan olahraga, serta sektor transportasi, komunikasi dan jasa keuangan.

1. Model VAR (1) untuk Sektor Inflasi

$$
\begin{aligned}
Y_{1, t}= & 1.330 Y_{1, t-1}-0.330 Y_{1, t-2}-43.688 Y_{2, t-1}+43.688 Y_{2, t-2}+36.339 Y_{3, t-1}-36.339 Y_{3, t-2}+ \\
& 15.662 Y_{4, t-1}-15.662 Y_{4, t-2}+2.574 Y_{5, t-1}-2.574 Y_{5, t-2}+3.612 Y_{6, t-1}-3.612 Y_{6, t-2}- \\
& 5.266 Y_{7, t-1}+5.266 Y_{7, t-2}-9.624 Y_{8, t-1}+9.624 Y_{8, t-2}+e_{1, t}
\end{aligned}
$$

2. Model VAR (1) untuk Sektor Makanan

$$
\begin{aligned}
Y_{2, t}= & 0.015 Y_{1, t-1}-0.015 Y_{1, t-2}+0.111 Y_{2, t-1}+0.889 Y_{2, t-2}+0.867 Y_{3, t-1}-0.867 Y_{3, t-2} \\
& +0.555 Y_{4, t-1}-0.555 Y_{4, t-2}-0.019 Y_{5, t-1}+0.019 Y_{5, t-2}-0.271 Y_{6, t-1}+0.271 Y_{6, t-2}- \\
& 0.346 Y_{7, t-1}+0.346 Y_{7, t-2}+0.199 Y_{8, t-1}-0.199 Y_{8, t-2}+e_{2, t}
\end{aligned}
$$


3. Model VAR (1) untuk Sektor Makanan Jadi, Minuman, Rokok Dan Tembakau

$$
\begin{aligned}
Y_{3, t}= & 0.005 Y_{1, t-1}-0.005 Y_{1, t-2}-0.311 Y_{2, t-1}+0.311 Y_{2, t-2}+1.007 Y_{3, t-1}-0.007 Y_{3, t-2}+ \\
& 0.202 Y_{4, t-1}-0.202 Y_{4, t-2}+0.285 Y_{5, t-1}-0.285 Y_{5, t-2}-0.154 Y_{6, t-1}+0.154 Y_{6, t-2}+ \\
& 0.206 Y_{7, t-1}-0.206 Y_{7, t-2}+0.151 Y_{8, t-1}-0.151 Y_{8, t-2}+e_{3, t}
\end{aligned}
$$

4. Model VAR (1) untuk Sektor Perumahan, Listrik, Air, Gas dan Bahan Bakar

$$
\begin{aligned}
Y_{4, t}= & 0.004 Y_{1, t-1}-0.004 Y_{1, t-2}-0.252 Y_{2, t-1}+0.252 Y_{2, t-2}-0.036 Y_{3, t-1}+0.036 Y_{3, t-2}+ \\
& 1.173 Y_{4, t-1}-0.173 Y_{4, t-2}+0.179 Y_{5, t-1}-0.179 Y_{5, t-2}+0.013 Y_{6, t-1}-0.013 Y_{6, t-2}+ \\
& 0.013 Y_{6, t-2}+0.036 Y_{7, t-1}-0.036 Y_{7, t-2}+0.244 Y_{8, t-1}-0.244 Y_{8, t-2}+e_{4, t}
\end{aligned}
$$

5. Model VAR (1) untuk Sektor Sandang

$$
\begin{aligned}
Y_{5, t}= & 0.002 Y_{1, t-1}-0.002 Y_{1, t-2}-0.166 Y_{2, t-1}+0.166 Y_{2, t-2}+0.035 Y_{3, t-1}-0.035 Y_{3, t-2}+ \\
& 0.147 Y_{4, t-1}-0.147 Y_{4, t-2}+1.202 Y_{5, t-1}-0.202 Y_{5, t-2}-0.127 Y_{6, t-1}+0.127 Y_{6, t-2}- \\
& 0.007 Y_{7, t-1}+0.007 Y_{7, t-2}+0.069 Y_{8, t-1}-0.069 Y_{8, t-2}+e_{5, t}
\end{aligned}
$$

6. Model VAR (1) untuk Sektor Kesehatan

$$
\begin{aligned}
Y_{6, t}= & 0.003 Y_{1, t-1}-0.003 Y_{1, t-2}-0.186 Y_{2, t-1}+0.186 Y_{2, t-2}+0.172 Y_{3, t-1}-0.172 Y_{3, t-2}+ \\
& 0.117 Y_{4, t-1}-0.117 Y_{4, t-2}+0.019 Y_{5, t-1}-0.019 Y_{5, t-2}+0.873 Y_{6, t-1}+0.127 Y_{6, t-2}- \\
& 0.027 Y_{7, t-1}+0.027 Y_{7, t-2}+0.040 Y_{8, t-1}-0.040 Y_{8, t-2}+e_{6, t}
\end{aligned}
$$

7. Model VAR (1) untuk Sektor Pendidikan dan Olahraga

$$
\begin{aligned}
Y_{7, t}= & 0.001 Y_{1, t-1}-0.001 Y_{1, t-2}-0.122 Y_{2, t-1}+0.122 Y_{2, t-2}-0.044 Y_{3, t-1}+0.044 Y_{3, t-2}+ \\
& 0.007 Y_{4, t-1}-0.007 Y_{4, t-2}+0.322 Y_{5, t-1}-0.322 Y_{5, t-2}-0.144 Y_{6, t-1}+0.144 Y_{6, t-2}+ \\
& 1.197 Y_{7, t-1}-0.197 Y_{7, t-2}+0.102 Y_{8, t-1}-0.102 Y_{8, t-2}+e_{7, t}
\end{aligned}
$$

8. Model VAR (1) untuk Sektor Transportasi dan Jasa Keuangan

$$
\begin{aligned}
Y_{8, t}= & 0.003 Y_{1, t-1}-0.003 Y_{1, t-2}-0.135 Y_{2, t-1}+0.135 Y_{2, t-2}+0.024 Y_{3, t-1}-0.024 Y_{3, t-2}+ \\
& 0.376 Y_{4, t-1}-0.376 Y_{4, t-2}-0.071 Y_{5, t-1}+0.071 Y_{5, t-2}-0.282 Y_{6, t-1}+0.282 Y_{6, t-2}+ \\
& 0.123 Y_{7, t-1}-0.123 Y_{7, t-2}+0.968 Y_{8, t-1}+0.032 Y_{8, t-2}+e_{8, t}
\end{aligned}
$$

\subsection{Peramalan Sektor Inflasi Menggunakan Model VAR (1)}

Hasil ramalan menggunakan model VAR yang telah ditentukan pada subbab 3.5. Model ini kemudian diaplikasikan pada data inflasi di Provinsi Gorontalo sehingga diperoleh hasil pada tabel 6. 
Tabel 6 Hasil Ramalan tahun 2019 berdasarkan model VAR (1)

\begin{tabular}{|l|l|l|l|l|l|l|l|l|}
\hline Bulan/ Tahun & $\mathrm{Y}_{1}$ & $\mathrm{Y}_{2}$ & $\mathrm{Y}_{3}$ & $\mathrm{Y}_{4}$ & $\mathrm{Y}_{5}$ & $\mathrm{Y}_{6}$ & $\mathrm{Y}_{7}$ & $\mathrm{Y}_{8}$ \\
\hline Januari 2019 & $-0,4869$ & 4,9003 & 4,9223 & 4,8148 & 4,7846 & 4,8557 & 4,7982 & 4,8765 \\
\hline Febuari 2019 & $-0,3938$ & 4,8970 & 4,9216 & 4,814 & 4,7843 & 4,8554 & 4,798 & 4,8762 \\
\hline Maret 2019 & $-0,2577$ & 4,9003 & 4,9228 & 4,815 & 4,7849 & 4,8561 & 4,7985 & 4,8766 \\
\hline April 2019 & $-0,3027$ & 4,9007 & 4,9228 & 4,815 & 4,7849 & 4,8561 & 4,7985 & 4,8768 \\
\hline Mei 2019 & $-0,3333$ & 4,9008 & 4,9225 & 4,8148 & 4,7848 & 4,8559 & 4,7984 & 4,8766 \\
\hline Juni 2019 & $-0,3166$ & 4,9008 & 4,9225 & 4,8148 & 4,7848 & 4,8559 & 4,7984 & 4,8766 \\
\hline Juli 2019 & $-0,3107$ & 4,9001 & 4,9226 & 4,8149 & 4,7848 & 4,856 & 4,7984 & 4,8766 \\
\hline Agustus 2019 & $-0,3161$ & 4,9000 & 4,9226 & 4,8149 & 4,7848 & 4,856 & 4,7984 & 4,8766 \\
\hline September 2019 & $-0,3169$ & 4,9000 & 4,9226 & 4,8148 & 4,7848 & 4,856 & 4,7984 & 4,8766 \\
\hline Oktober 2019 & $-0,3154$ & 4,9000 & 4,9226 & 4,8148 & 4,7848 & 4,856 & 4,7984 & 4,8766 \\
\hline November 2019 & $-0,3154$ & 4,9000 & 4,9226 & 4,8149 & 4,7848 & 4,856 & 4,7984 & 4,8766 \\
\hline Desember 2019 & $-0,3158$ & 4,9000 & 4,9226 & 4,8148 & 4,7848 & 4,856 & 4,7984 & 4,8766 \\
\hline
\end{tabular}

Berdasarkan Tabel 6 diketahui bahwa pada awal tahun 2019 inflasi di provinsi Gorontalo terbilang sangat rendah yakni sekitaran $-0,48 \%$ sampai $-0,40 \%$. Akan tetapi inflasi akan melonjak naik drastis pada bulan Maret 2019 dengan tingkat inflasi sebesar -0,25\% (tingkat inflasi tertinggi ada pada bulan Maret 2019). Hal ini perlu diwaspadai oleh para investor dan pemerintah khususnya masyarakat karena kenaikan inflasi ini dapat menyebabkan kenaikan harga yang cukup besar, sehingga efeknya terhadap perekonomian lebih berat, dibandingkan jika kenaikan laju inflasi yang lambat. Pada bulan April dan Mei inflasi mengalami penurunan menjadi $-0,30 \%$ dan $-0,33 \%$. Setelah mengalami penurunan tingkat inflasi pada bulan April dan Mei, pada pertengahan tahun (bulan Juni) inflasi di provinsi Gorontalo akan mengalami peningkatan kembali menjadi $-0,31 \%$ dan tidak akan mengalami banyak perubahan sampai akhir tahun yakni tetap berkisar di angka $-0,32 \%$

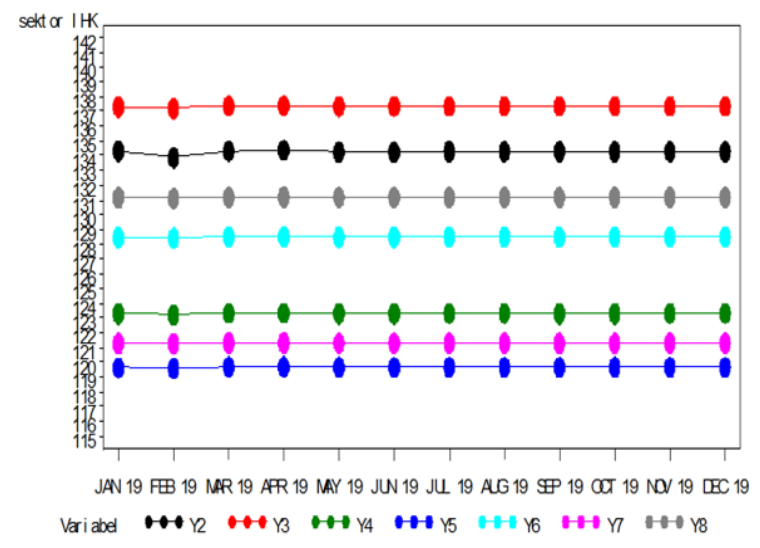

Gambar 3 Plot Peramalan Sektor IHK 2019

Pada Gambar 3, faktor yang mempengaruhi inflasi juga mempunyai ramalan yang serupa. Sektor IHK menunjukkan pada pola trend dari awal tahun yakni Januari sampai bulan Mei 2019, kemudian sektor IHK mengalami penurunan pada bulan juni dan cenderung konstan sampai akhir tahun 2019. Kenaikan sektor IHK pada awal tahun khususnya pada bulan maret kemungkinan menyebabkan kenaikan laju inflasi di provinsi Gorontalo. Pada peramalan tahun 2019, Sektor IHK terendah ada pada sektor sandang, sedangkan sektor tertinggi ada pada sektor makanan jadi, minuman, rokok dan tembakau. Hal ini mengindikasikan bahwa pada tahun 2019 sektor makanan jadi, minuman, rokok dan tembakau mempunyai tingkat harga yang lebih tinggi dibandingkan sektor IHK lainnya. 
Inflasi merupakan salah indikator ekonomi yang dapat menunjukkan baik/buruknya perekonomian suatu daerah. Tingkat inflasi tinggi, menggambarkan perlambatan laju pertumbuhan ekonomi, tetapi terjadinya deflasi tidak selalu menggambarkan hal yang positif. Angka inflasi yang stabil yang menunjukan bahwa indikator perekonomian semakin baik. Kenaikan inflasi pada bulan Maret (hasil peramalan) kemungkinan dipengaruhi oleh kenaikan tingkat inflasi pada bulan yang sama pada tahun sebelumnya yakni 2018, dimana dari data yang ada diketahui inflasi untuk bulan Februari tahun 2018 adalah -0,84 melonjak naik menjadi 0,34. Selain itu, kenaikan inflasi dapat juga dipengaruhi oleh kenaikan sektorsektor IHK (hasil ramalan). Berdasarkan model VAR(1) yang menyatakan bahwa tingkat inflasi di Provinsi Gorontalo dipengaruhi oleh sektor inflasi satu bulan dan dua bulan sebelumnya, sektor makanan satu bulan dan dua bulan sebelumnya, serta sektor makanan jadi, minuman dan tembakau satu bulan dan dua bulan sebelumnya. Berdasarkan informasi dari pihak BPS Provinsi Gorontalo, diketahui bahwa kenaikan yang drastis pada bulan Maret tahun 2018 disebabkan karena adanya kenaikan indeks di tiga kelompok pengeluaran atau di tiga sektor IHK. Sektor IHK yang mengalami kenaikan indeks adalah sektor bahan makanan sebesar $1,46 \%$, sektor sandang sebesar $0,45 \%$ dan sektor pendidikan, rekreasi dan olahraga sebesar $0,01 \%$. Sehingga terbukti bahwa sektor-sektor IHK mempengaruhi kenaikan dan penurunan inflasi.

\subsection{Ukuran Ketepatan Peramalan}

Kinerja model yang digunakan dalam peraamalan dapat dilihat pada Mean Absolute Precentase Error (MAPE) dari data out sample. Hasil perhitungan MAPE dapat dilihat pada tabel 7.

Tabel 7 Nilai MAPE pada Masing-Masing Indikator

\begin{tabular}{|l|l|l|l|l|l|l|l|}
\hline $\mathrm{Y}_{1}$ & $\mathrm{Y}_{2}$ & $\mathrm{Y}_{3}$ & $\mathrm{Y}_{4}$ & $\mathrm{Y}_{5}$ & $\mathrm{Y}_{6}$ & $\mathrm{Y}_{7}$ & $\mathrm{Y}_{8}$ \\
\hline 2,79474 & 0,96479 & 0,96508 & 0,961082 & 0,96055 & 0,962327 & 0,96106 & 0,96313 \\
\hline
\end{tabular}

Berdasarkan tabel 7 didapatkan nilai (MAPE) diperoleh dari data out sampel variabel $\mathrm{Y}_{1}$ sampai $\mathrm{Y}_{8}$ rata-rata dibawah $10 \%$, sehingga dapat dikatakan bahwa kinerja model sangat baik. Dari nilai tersebut dapat disimpulkan bahwa hasil estimasi model VAR optimal mempunyai kemampuan peramalan yang sangat baik dengan keakuratan yang sangat tinggi.

\section{KESIMPULAN}

Model Vector Autoregressive (VAR) pada inflasi di Provinsi Gorontalo adalah model VAR(1) yang dituliskan sebagai berikut. Berdasarkan model $V A R(1)$ dan pengujian signifikansi parameter diketahui bahwa sektor inflasi dipengaruhi oleh sektor makanan satu bulan sebelumnya, serta sektor makanan jadi, minuman dan tembakau. Berdasarkan hasil dari VAR(1) terbaik, Hasil peramalan inflasi di provinsi Gorontalo untuk tahun 2019 menunjukkan bahwa pada awal tahun 2019 inflasi di provinsi Gorontalo terbilang sangat rendah yakni sekitaran $-0,48 \%$ sampai $-0,40 \%$. Akan tetapi inflasi akan melonjak naik pada bulan Maret 2019 dengan tingkat inflasi sebesar -0,25\% (tingkat inflasi tertinggi ada pada bulan Maret 2019). Pada bulan April dan Mei inflasi mengalami penurunan menjadi -0,30\% dan $-0,33 \%$. Setelah mengalami penurunan tingkat inflasi pada bulan April dan Mei, pada pertengahan tahun (bulan Juni) inflasi di provinsi Gorontalo mengalami peningkatan kembali menjadi $-0,31 \%$ dan tidak akan mengalami banyak perubahan sampai akhir tahun yakni tetap berkisar di angka $-0,32 \%$. Keakuratan hasil prediksi dilihat pada nilai $M A P E$ dari data out sampel variabel $\mathrm{Y}_{1}$ sampai $\mathrm{Y}_{8}$ rata-rata dibawah $10 \%$ menunjukan bahwa hasil estimasi model VAR (1) mempunyai kemampuan peramalan yang sangat baik. 


\section{DAFTAR PUSTAKA}

BPS. (2018), "Indeks harga Konsumen dan Inflasi," Available athttps://gorontalo.bps.go.id/subject/3/inflasi.html\#subjekViewTab3.

Desvina, A. P., and Juliana, M. (2016), "Pemodelan Pencemaran Udara Menggunakan Metode Vector Autoregressive(VAR) di Provinsi Riau," SiTekIn: Jurnal Sains dan Teknologi, 13, 160-167. http://dx.doi.org/10.24014/sitekin.v13i2.1669.

Ekananda, M. (2016), Analisis Ekonometrika Dan Analisis Time Series, Jakarta: Mitra Wacana Media.

Hardani, P. R., Hoyyi, A., and Sudarno, S. (2016), "Peramalan Laju Inflasi,Suku Bunga Indonesia dan Indeks Harga Saham Gabungan menggunakan Metode Vector Autoregressive (VAR)," Jurnal Gaussian, 6, 101-110.

Hendajany, N. (2015), “Tingkat Inflasi Suku Bunga Bank Indonesia Jumlah Uang Beredar dan Kurs," Eko-Regional: Jurnal Pembangunan Ekonomi Wilayah, 10, 39-47. https://doi.org/10.20884/1.erjpe.2015.10.1.756.

Ohyver, M. (2013), "Penerapan Metode Transpormasi Logaritma Natural dan Partial Least Square untuk memperoleh Model Bebas Multikoliner dan Outlier," Jurnal Mat Stat, $13,42-51$.

Prahutama, A., Suparti, S., Ispriyanti, D., and Utami, T. W. (2019), "Modelling Inflation Sectors in Indonesia Using Vector Autoregressive (VAR)," Jurnal ILMU DASAR, 20, 47. https://doi.org/10.19184/jid.v20i1.7259.

Suhel, S. (2008), “Analisis Model Vector Auto Regression (VAR) Terhadap Hubungan Antara Pertumbuhan Ekonomi Dengan Penanaman Modal Asing (PMA) di Indonesia," Jurnal Ekonomi Pembangunan, 6, 96-113. https://doi.org/10.29259/jep.v6i2.4855.

Supranto, J. (2005), Ekonometrika Buku Kesatu, Bogor: Ghalia Indonesia. 